\title{
CONSTITUTIONAL MORTALITY: PRECEDENTIAL EFFECTS OF STRIKING THE INDIVIDUAL MANDATE
}

\author{
MARK A. HALL*
}

Defenders of health insurance reform might rightly claim that blood will be on the hands of a court that strikes down the Patient Protection and Affordable Care Act (ACA). ${ }^{1}$ Because insurance is necessary for decent access to healthcare, some analysts estimate that being uninsured kills 20,000 or more people a year. ${ }^{2}$ Considering that the ACA reduces the number of uninsured by more than half, ${ }^{3}$ it stands to reason that eliminating the ACA could cost more than 10,000 lives a year. Even if only the individual mandate were stricken, thousands could die each year, according to estimates that the ensuing market chaos would cut the Act's insurance gains in half.

As sobering as these statistics are, far more chilling is the loss of life that might result from the constitutional precedent that a negative ACA ruling could set. The challengers' chief argument is that the Commerce Clause confers no federal authority-no matter how dire the necessity-simply to mandate behavior, unconditioned on citizens engaging in some economic activity. This argument's frightening prospect is that this very power might someday be absolutely essential to saving a million or more lives, based on solid public health science, in the event of a catastrophic public health emergency.

Imagine, for instance, a pandemic similar to the 1918 influenza that killed over half a million Americans. ${ }^{5}$ Public health authorities warn that, eventually,

Copyright () 2012 by Mark A. Hall.

This article is also available at http://lcp.law.duke.edu/.

* Fred and Elizabeth Turnage Professor of Law and Public Health, Wake Forest University. Samantha Vaillancourt provided helpful research assistance, and Neil Siegel, Peter Jacobson, and Wendy Parmet shared insightful comments. U.S.C.).

1. Pub. L. No. 111-148, 124 Stat. 119 (2010) (codified as amended in scattered sections of 42

2. Stan Dorn, URban Inst., Uninsured and Dying Because of It: Updating the INSTITUTE OF MEDICINE ANALYSIS ON THE IMPACT OF UNINSURANCE ON MORTALITY 3 (2008), available at http://www.urban.org/url.cfm?ID=411588; Andrew P. Wilper et al., Health Insurance and Mortality in US Adults, 99 AM. J. PUB. HEALTH 2289, 2294 (2009).

3. Letter from Congressional Budget Office to U.S. Rep. Nancy Pelosi 9 (Mar. 20, 2010), http://www.cbo.gov/ftpdocs/113xx/doc11379/amendreconProp.pdf.

4. CONG. Budget OFFICE, EFFECTS OF ELIMINATING THE INDIVIDUAL MANDATE TO OBTAIN HEALTH INSURANCE 2 (2010), available at http://www.cbo.gov/ftpdocs/113xx/doc11379/ Eliminate_Individual_Mandate_06_16.pdf.

5. PRESIDENT's COUNCIL OF AdVISORS ON SCI. \& TECH., EXEC. OfFICE OF THE PRESIDENT, 
such an outbreak is a very real possibility, and could kill several times more people in the modern era. ${ }^{6}$ Or consider a nuclear-reactor meltdown like that in Chernobyl, or that almost happened in Japan following recent earthquakes. Minimizing deaths from such disasters requires forceful federal action, but the precedent that ACA challengers seek might tie federal hands.

Insurance-mandate opponents fret over what vegetables the government might force them to purchase if the mandate were upheld. ${ }^{7}$ But courts, rather than obsessing over slippery slopes toward ridiculous mandates, should be much more concerned about the high hurdles to appropriate federal health action that a nullifying precedent would erect. As Chief Justice Marshall first reminded us almost two centuries ago, ours is "a Constitution intended to endure for ages to come, and consequently to be adapted to the various crises of human affairs."

State and local public health authorities historically have been the first line of defense against public health and natural disasters.' But, in the modern world, when local measures prove inadequate, the federal government wisely has contingency plans to take measures necessary to protect the public's health and safety. ${ }^{10}$ The Public Health Service Act, for instance, allows the Surgeon General to provide for "the apprehension and examination of any individual reasonably believed to be infected with a communicable disease in a communicable stage and ... to be a probable source of infection to individuals who ... will be moving from a State to another State." "This authority covers not only those who are in active movement, but also those who might spread disease to people who travel. Thus, according to leading public health law authorities, "because virtually any infected person could be a source of infection to others who might be traveling from state to state, jurisdiction over quarantine and isolation is effectively concurrent between state and federal governments." ${ }^{12}$

Another source of emergency federal power is the Department of Homeland Security's "National Response Framework." It contains provisions for "catastrophic incidents," defined as "any natural or manmade incident ...

U.S. PREPARATIONS FOR 2009-H1N1 INFLUENZA 8 (2009), available at http://www.whitehouse.gov/ assets/documents/PCAST_H1N1_Report.pdf.

6. Robert G. Webster \& Elizabeth Jane Walker, Influenza: The World is Teetering on the Edge of a Pandemic that Could Kill a Large Fraction of the Human Population, AM. SCIENTIST, Mar.-Apr. 2003 , at $122,127$.

7. Ilya Somin, A Mandate for Mandates: Is the Individual Health Insurance Case a Slippery Slope?, 75 LAW \& CONTEMP. PROBS., no. 3, 2012 at 75, 85.

8. McCulloch v. Maryland, 17 U.S. (4 Wheat.) 316, 415 (1819).

9. Theodore Ruger, Of Icebergs and Glaciers: The Submerged Constitution of American Healthcare, 75 LAW \& CONTEMP. PROBS., no. 3, 2012 at 215, 227.

10. David P. Fidler, Constitutional Outlines of Public Health's "New World Order", 77 TEMP. L. REV. 247, 254-55 (2004) (noting an increasing federal role in public health because of interstate commerce and national security concerns).

11. 42 U.S.C. $\$ 264(a)(1)(2006)$.

12. Peter D. Jacobson et al., The Role of Law in Public Health Preparedness: OpPortunities AND Challenges, FinAl Report to the CENTERS FOR DiseASE CONTROL 182 (Apr. 23, 2010) (on file with the author and Law and Contemporary Problems). 
that results in extraordinary levels of mass casualties, damage, or disruption severely affecting the population, infrastructure, environment, economy, national morale, and/or government functions." ${ }^{13}$ The plan recognizes that a catastrophic incident "could result in sustained nationwide impacts over a prolonged period of time [that] almost immediately exceed[] resources normally available to State, tribal, local, and private-sector authorities in the impacted area .... These factors drive the urgency for coordinated national planning to ensure accelerated Federal and/or national assistance. ${ }^{14}$ The plan continues:

Where State, tribal, or local governments are unable to establish or maintain an effective incident command structure due to catastrophic conditions, the Federal Government, at the direction of the Secretary of Homeland Security, may establish a unified command structure ... to save lives, protect property, maintain operation of critical infrastructure/key resources (CIKR), contain the event, and protect national security.

Despite this mention of national security, the Commerce Clause is the primary-sometimes only-constitutional basis for emergency federal powers. For cases in which the federal government's preparedness and response role is simply facilitative-providing resources and guidance, for example-Congress's taxing and spending power suffices. ${ }^{16}$ Or, if disaster results from terrorism, military powers obviously kick into gear. For natural and public health disasters, however, the Commerce Clause is the critical source of power if strong federal measures are required. ${ }^{17}$

According to the Congressional Research Service, the "authority of the federal government to prescribe quarantine and other health measures is based

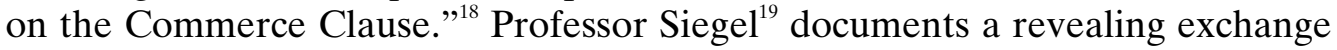
between then-Solicitor General Kagan and Justices Scalia and Kennedy in a 2010 oral argument. The Justices note, and Kagan agrees, that communicable disease falls clearly within the scope of the Commerce power. Justice Scalia observed: "[I]f anything relates to interstate commerce, it's communicable diseases." Kennedy remarked: "[T]hat's a pretty easy commerce power argument. ${ }^{, 20}$ Professor Siegel correctly explains that natural disasters sometimes

13. U.S. DeP'T OF Homeland SEC., NATIONAL RESPONSE Framework: CATASTrophic INCIDENT ANNEX CAT-1 (2008), available at http://www.fema.gov/pdf/emergency/nrf/nrf_ CatastrophicIncidentAnnex.pdf.

14. Id.

15. Id.

16. See Lawrence O. Gostin, Public Health Law: Power, Duty, Restraint 103 (2d ed. 2008) (reviewing various bases for federal public health powers).

17. See Michael Greenberger, The Alfonse and Gaston of Governmental Response to National Public Health Emergencies: Lessons Learned from Hurricane Katrina for the Federal Government and the States, 58 ADMIN. L. REV. 611, 617-18 (2006) ("[A]ny catastrophic public health disaster is likely to be considered subject to Congress's commerce powers.").

18. CONG. RESEARCH SERV., FEDERAL AND STATE QUARANTINE AND ISOLATION AUTHORITY 2 (2007), available at $\mathrm{http} / / / \mathrm{www}$. fas.org/sgp/crs/misc/RL33201.pdf.

19. Neil Siegel, Free Riding on Benevolence: Collective Action Federalism and the Minimum Coverage Provision, 75 LAW \& CONTEMP. PROBS., no. 3, 2012 at 29, 53 n.150.

20. Id.; see also Ruger, supra note 9, at 229 (quoting from 1886 Supreme Court decision scolding Congress for not using its commerce power "to protect the people from the ravages of these dreadful 
have direct spillover impacts on multiple states, by forcing people to relocate and requiring out-of-state assistance. ${ }^{21}$

For federal response to be effective, these emergency Commerce Clause powers must include authority to mandate citizen behavior, regardless of engagement in commerce. Quarantine is the principal emergency federal power supported by the Commerce Clause. On its face, isolating an infected or exposed person might appear to merely restrict rather than compel activity, but quarantine orders are often coupled with behavior mandates to make them fully effective.

Epidemiologists project that merely ordering everyone to stay home will not suffice to halt a pandemic unless there is virtually $100 \%$ compliance. ${ }^{22}$ Short of that, some form of mandatory "prophylaxis" will be needed, and this entails many forms of mandated behavior. States, for instance, routinely mandate vaccinations to prevent infectious disease. In more extreme situations, the Model State Emergency Health Powers Act includes powers to mandate medical examination, testing, and treatment. ${ }^{23}$ Sensible responses to a pandemic might entail measures as prosaic as requiring people to wash their hands or to purchase gauze masks. ${ }^{24}$ Yet an anti-ACA precedent would bar all of these federal measures, unless they are somehow conditioned on engaging in voluntary economic activity.

People in quarantine or isolation at home typically are required to wear masks and to report their symptoms. The U.S. Centers for Disease Control and Prevention's (CDC) sample home-quarantine order, for instance, provides: "While in quarantine, you must wear a surgical mask at all times while in the presence of any individual, including any caregiver.... The County Health Department (CHD) will call your residence daily to obtain your temperature record, which you must take and record two times daily.",25

Similarly, in response to the SARS outbreak in 2003, the "instructions for quarantine [in Toronto] included sleeping separately from others, using personal items (e.g., utensils and towels) exclusively (i.e., not sharing them),

[contagious] diseases" of cholera and yellow fever).

21. Siegel, supra note 19, at 62.

22. See Neil M. Ferguson et al., Strategies for Mitigating an Influenza Pandemic, 442 NATURE 448, 448 (2006).

23. The Model StATE EMERgency HeAlth POWERS Act, available at http://www.publichealthlaw.net/MSEHPA/MSEHPA.pdf; see also Gene Matthews et al., Legal Authorities for Interventions in Public Health Emergencies, in LAW IN PUBLIC HEALTH PRACTICE 262, 271 (Richard E. Hoffman et al. eds., 2d ed. 2006) (noting that state powers include contact tracing, medical exams and treatment, and mandatory reporting of symptoms).

24. During the 1918 flu pandemic, for instance, San Francisco and San Diego made gauze masks "a requirement of the entire population." The following rhyme reminded people of the ordinance: "Obey the laws / And wear the gauze / Protect your jaws / From Septic Paws." Molly Billings, The Influenza Pandemic of 1918: The Public Health Response (June 1997), http://virus.stanford.edu/ uda/fluresponse.html.

25. U.S. Ctrs. for Disease Control \& Prevention, Sample Quarantine to Residence Order, http://www2a.cdc.gov/phlp/docs/FL\%20Quarantine\%20To\%20Residence\%20Order\%20Apr\%2009\%2 0252.pdf (emphasis added). 
and wearing a mask when near household members." ${ }^{26}$ The constitutional principle that ACA opponents champion would bar such measures. It would be a very peculiar Constitution, though, that permitted quarantine but forbade much milder mandates, even if public health authorities insist they are needed to make quarantine safe and effective. ${ }^{27}$ Professor Somin suggests that such mandates can be conditioned on some other behavior affecting commerce ${ }^{28}$ but sometimes the only behavioral hook readily available is, literally, simply breathing.

It is also quite likely that emergency federal powers include authority to require people to turn over items of personal property. To prevent the spread of communicable disease in interstate commerce, "the Surgeon General may provide for such inspection, fumigation, disinfection, sanitation, pest extermination, destruction of animals or articles found to be so infected or contaminated as to be sources of dangerous infection to human beings, and other measures, as in his judgment may be necessary." ${ }^{29}$ The statute does not limit this authority to only articles or animals that authorities search out on their own, or even to those in transit. Instead, it appears to permit requiring citizens themselves to affirmatively report or relinquish such dangerous items or animals. But this too would be forbidden by a precedent striking down the ACA's mandate on the grounds that it constituted the regulation of inactivity.

In addition to the public health mandates that federal law currently contemplates, consider also the possible need for Congress to further expand federal authority in the future, learning from prior experiences and anticipating new threats. Federal power to mandate evacuation or vaccination, for instance, might be needed to save large numbers of lives under various catastrophic scenarios. Professor Somin asserts that state and local authority should be adequate to deal with most major public health crises and natural disasters ${ }^{30}$ but that hope was not borne out by Katrina, ${ }^{31}$ or even by the mild H1N1 "swine flu." "32 Over the past decade, each new crisis has led to studies documenting the inadequacy of state and local responses and calls for a more proactive federal

26. Tomislav Svoboda et al., Public Health Measures to Control the Spread of the Severe Acute Respiratory Syndrome During the Outbreak in Toronto, 350 NEW. ENG. J. MED. 2352, 2354 (2004).

27. See Ferguson et al., supra note 22, at 450 (recommending "a combined policy of household quarantine and household prophylaxis" because "[b]eing a member of a household containing an influenza case is in fact the largest single risk factor for being infected oneself").

28. Somin, supra note 7 , at 81 .

29. 42 U.S.C. $\$ 264($ a) (2006).

30. Somin, supra note 7, at 101.

31. The Federal Response to Hurricane Katrina: Lessons Learned (Feb. 23, 2006), http://georgewbush-whitehouse.archives.gov/reports/katrina-lessons-learned/index.html; Greenberger, supra note 17, at 611; Stephen M. Griffin, Stop Federalism Before It Kills Again: Reflections on Hurricane Katrina, 21 ST. JOHN's J. LEGAL COMMENT. 527 (2007).

32. Ass'N OF StATE \& TERritorial HEALTH OFFICIALS, AsSESSING Policy BARRIERS To EFFECTIVE Public HeAlth Response In THE H1N1 InFLuENZA PANDEMiC (2010), available at http:/www.astho.org/programs/infectious-disease/h1n1/. 
response. ${ }^{33}$ As a comprehensive report to the CDC concludes:

The emergence of these public health threats has prompted robust efforts to improve United States emergency preparedness at all levels of government. While states and localities have traditionally had primary responsibility for conducting these kinds of public health activities, it has become clear that there is also a salient need for federal involvement in preparing for and responding to public health emergencies.... This shift represents a departure from the traditional federal-state relationship in the area of emergency preparedness.

Or as a House of Representatives investigative report on Katrina warns, "faith in federalism alone cannot sanctify a dysfunctional system in which [federal agencies] simply wait for requests for aid that state and local officials may be unable or unwilling to convey. ${ }^{35}$ Future Katrinas, for instance, might necessitate mandatory federal evacuation orders. This again would appear to be barred by a Commerce Clause ruling that restricts the federal government from mandating the behavior of the general citizenry.

State and local authorities tend to respond poorly to pandemic or mass casualty events not only because they are overwhelmed, but because they are also unaccustomed to using their strongest powers on a population-wide basisas opposed to more typical isolated events that affect only a few individuals. ${ }^{36}$ In community-wide disaster conditions, local officials may hesitate to take decisive action, uncertain about the full extent and proper exercise of authority under state law. ${ }^{37}$ According to the leading study conducted for the CDC, "our results paint a somewhat grim picture of the degree to which public health emergency preparedness stakeholders, at all levels of government, have internalized the relevant provisions of applicable laws and are fully prepared to act on that knowledge when faced with a large scale health incident." ${ }^{38}$

33. See, e.g., Brad Kvinta, Quarantine Powers, Biodefense, and Andrew Speaker, $1 \mathrm{~J}$. BIOSECURITY, BIOSAFETY \& BIODEFENSE L., no. 1, art. 5, 2011 at 1, 2, available at http://www.bepress.com/jbbbl/vol1/iss1/5/ (discussing the 2007 case of Andrew Speaker, a tuberculosis patient who federal authorities apprehended after he ignored state and local commands); Wendy E. Parmet, Legal Power and Legal Rights-Isolation and Quarantine in the Case of Drug-Resistant Tuberculosis, 357 NEW ENG. J. MED. 433, 433 (2007).

34. Benjamin E. Berkman et al., Assessing the Impact of Federal Law on Public Health Preparedness, 4 St. LOUIS J. HEALTH REFORM 155, 156 (2010).

35. SElECT BipartisAn COMM. TO INVESTIGATE THE PREPARATION FOR AND RESPONSE TO Hurricane Katrina, U.S. HOUSE of RePresentatives, A FaILURe Of Initiative: Final REPORT (2006), available at http://www.gpoaccess.gov/katrinareport/fullreport.pdf.

36. Matthews et al., supra note 23, at 267.

37. Anda Botoseneanu et al., Achieving Public Health Legal Preparedness: How Dissonant Views On Public Health Law Threaten Emergency Preparedness and Response, 33 J. PuB. HeAlth 361 (2011); JACOBSON ET AL., supra note 12, at 321 ("Our research reveals an objective legal environment that is composed of a patchwork of federal and state laws and regulations governing routine and emergency public health scenarios, leaving important legal gaps. In some instances, the details of existing laws are vague or conflicting, making it difficult for practitioners and officials to implement. For many other issues, little to no legal framework exists to guide public health practitioners.").

38. JACOBSON ET AL., supra note 12, at 55. 
Professor Parmet rightly warns that "[d]ogmatic and rigid visions of federalism can imperil the public health whether the threat is natural or manmade. ${ }^{\prime 39}$ Whether it is vaccination and evacuation or merely buying gauze masks and reporting infectious symptoms, a fuller range of emergency federal powers will almost certainly include some mandated behaviors that are unconditioned on economic activity. If exaggerated federalist concerns produce an overly fastidious construction of the Commerce Clause in the fashion that ACA challengers request, no such federal power would be allowed. If that were to transpire, doomsday predictions may not be hyperbolic; instead, they may prove to be prophetic.

39. Wendy E. Parmet, After September 11: Rethinking Public Health Federalism, 30 J.L. MED. \& ETHICs 201, 201 (2002); see also Griffin, supra note 31, at 528. 